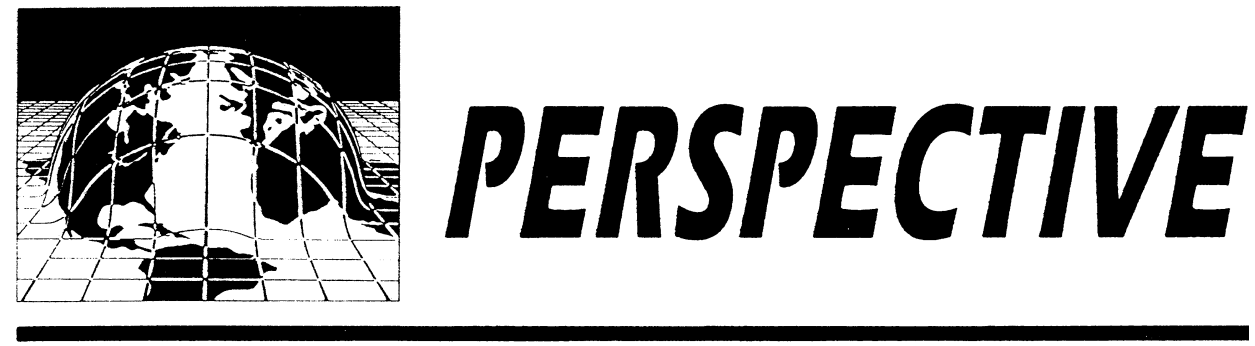

\title{
The Interdependence of Private and Public Interests
}

\author{
Joseph T. Mahoney \\ College of Business, University of Illinois at Urbana-Champaign, Champaign, Illinois 61820, josephm@illinois.edu \\ Anita M. McGahan \\ AIC Institute for Corporate Citizenship, Rotman School of Management, University of Toronto, \\ Toronto, Ontario M5S 3E6, Canada, and Department of Global Health and Social Medicine, \\ Institute for Strategy and Competitiveness, Harvard University, Boston, Massachusetts 02130, \\ amcgahan@ rotman.utoronto.ca \\ Christos N. Pitelis \\ Centre for International Business and Management, Judge Business School, University of Cambridge, \\ Cambridge CB2 1AG, United Kingdom, c.pitelis@jbs.cam.ac.uk
}

\begin{abstract}
$\mathrm{T}_{\mathrm{s}}^{\mathrm{s}}$ he predominant focus in research on organizations is on private or public institutions without consistent consideration of their interdependencies. The emphasis in scholarship on private or public interests has strengthened as disciplinary and professional knowledge has deepened: Management scholars, for example, tend to consider the corporation as the unit of analysis, whereas scholars of public policy often analyze governmental, multilateral, community, and nonprofit organizations. This article advocates a partial merging of these research agendas on the grounds that private and public interests cannot be fully understood if they are conceived independently. We review three major areas of activity today in which public and private interests interact in complex ways and maintain that current theories of organization science can be deployed to understand these interactions better. We also suggest that theories of public-private interaction require development and describe a concept called global sustainable value creation, which may be used to identify organizational and institutional configurations and strategies conducive to worldwide, intertemporal efficiency and value creation. We conclude that scholarship on organizations would advance if private-public interactions were evaluated by the criterion of global sustainable value creation, and we identify organizational research opportunities that jointly consider public and private interests.
\end{abstract}

Key words: private-public interaction; sustainable value creation

History: Published online in Articles in Advance September 25, 2009.

\section{Introduction}

The field of organization science is devoting greater attention to the interdependence between private and public interests. The December 2005 issue of the Academy of Management Journal contained several related articles on management and public policy, and a recent issue of the International Journal of Industrial Organization (2008) focuses on public-private partnerships. Despite this increased attention, research studies that deal specifically with relationships between private and public interests (sometimes referred to as "the general welfare" or "common good") continue to be exceptional (Carlsson 2008). In this article, we maintain that the field of organization science would be greatly served by a consis- tent, sustained focus on the connections between public and private interests (Glachant and Saussier 2006, Rangan et al. 2006).

Worldwide discussion on public and private interests is currently at a fever pitch over the global financial crisis. The issue vividly shows that public and private interests cannot be fully understood if they are conceived as separate (Barney 2005, Hitt 2005, Jacobides 2008). In general, public interests are well defined only when private interests can be aligned or aggregated cogently. Almost without exception, the public interest favors some private interests over others. Ill-defined public interests may favor specific organizations and individuals whose interests would not be favored if all members 
of a community were represented equally. In general, public interests run along a spectrum from poorly to well defined. Under this conceptualization, specific interests may become more or less aligned over time and shift in character between private and public.

Private and public action may also activate the degree of alignment in interests, thus creating endogeneity in the public interest. For example, private transactions in subprime lending led to a substantial drop in the economic value of federally guaranteed mortgages in the United States (Coleman et al. 2008, Cowan and Cowan 2004), which in turn created a public interest in stabilizing the financial system. Also, public actions such as the release of oil reserves in the wake of high prices have substantive economic implications for private firms that invest in oil-extraction technologies under initial uncertainty around a government's release policy (Just et al. 2004). Furthermore, large firms with geographically diverse, specialized activities influence macroeconomic trade flows and economic development (Dunning 1993). These examples of how private and public interests interact and are inseparable illustrate the challenge of identifying interests, organizations, activities, and institutions as independently private and public (Ostrom 1990).

Conceptualizing public policy and especially the public interest has long been the subject of a rich research literature in the social sciences. Classical economists, including Smith (1776), considered the public interest as the overall wealth of society. Drawing on research by Robbins (1935), neoclassical economists used "allocative efficiency" as a fundamental criterion for identifying effective economic policy in the public interest, with this key criterion defined as the generation of consumer and producer welfare through the effective deployment of scarce resources. Subsequently, organization scholars developed alternative criteria for determining actions in the public interest that emphasize intertemporal wealth creation under resource scarcity and identified how rewards to innovative investment are directed (Penrose 1959).

Our approach in this article is complementary to this extant research literature and conceives of public interests as a complex amalgam of interdependent individual and private interests (along the lines of Mahoney and McGahan 2007). This perspective follows the tradition of Arrow's (1951) impossibility theorem, which points to the theoretical intractability of aggregating private interests into a well-defined public interest. We also conceive of public and private interests as changing over time, as suggested in Doering's (2007) presidential address to the American Agricultural Economics Association, which noted that most societies go through periods when public goods become quasipublic or private goods and that the opposite process occurs as well (Hirschman 1982). The changing concept of public goods throughout the economic history of the United States is documented in North (1990). Salient contemporary examples include higher education being increasingly valued principally as a private good (Burch 2009), and the $\$ 700$ billion bailout of Wall Street enterprises in which specific private institutions may be fundamentally transformed to become quasipublic institutions (Zingales 2008).

Public (or "collective," Mishan 1982) and private goods are typically conceived as distinctive theoretical constructs, but we emphasize here that the nuanced contextual details of interests can reveal that a particular good may simultaneously have a public and private character. Furthermore, we maintain that the concept of "public or collective goods" should be expanded to allow for multiple levels of community, and particularly the global community. In other words, the unit of analysis for understanding the public interest is itself complex (Ostrom 1990). An alignment of private interests may occur at the level of the community, state, or nation, yet competing national interests, for example, may mean the global public interest is poorly defined.

We also discuss the idea that many private interests are defined by reference to public institutions, practices, norms, and incentives; for example, the private interests of public corporations arise from the legal, social, and cultural context that establishes the public corporation as a juristic person with limited liability. Private interests are often shaped by global collective goods, which are defined as nonexcludable across borders, generations, and population groups (Kaul et al. 1999). Knowledge flow is the canonical example of a global public and collective good (Bell and Zaheer 2007, Stiglitz 1999). Health, peace, security, and a clean environment are examples of public and collective goods that may be global. Potentially catastrophic air pollution is a salient example of a global collective good that generates extensive negative externalities (Lee and Alm 2004). Increasingly, international institutions such as the United Nations and the World Bank are redefining their missions in terms of providing global public and collective goods, which often differentially shape private interests across geographical areas and over time.

These examples indicate that private and public interests are interdependent, yet, historically, private and public organizations have been examined primarily in research settings that emphasize one or the other exclusively. In particular, corporations have been studied principally by scholars of management and public institutions have been the province of economics, political science, education, public health, and public policy. As a consequence, research has tended to emphasize, first, how private organizations such as corporations can be constrained in the public interest through regulation and other public policy (Spulber 1989), and second, how public organizations can benefit from insights 
about the organizational systems, structures, and practices of private organizations (Simon 1976). Research at the boundaries tended to show how problems of the commons (or externalities) emerge in the aggregation of interests (Dahlman 1979, Libecap 1989, Stiglitz 1989). However, little research has been devoted to the complex character of many organizations as simultaneously public and private (Doering 2007, Huet and Saussier 2003, Stiglitz 1998). Notable exceptions include the research by Henisz and Zelner (2003) on nonmarket strategies and the interplay between business and public policy, Knott and Posen's (2005) work on entry and exit in banking, the study of Ouchi et al. (2005) on public schools, and Mahoney and McGahan's concern over "pervasive and worsening poverty among vast populations of the economically disenfranchised; naturalresource depletion; energy challenges; digitization; the globalization of many industries; the prospect of skyrocketing interest rates; the integration of capital markets across many countries; corruption and terrorism" (2007, p. 85). Ouchi (2006) compares innovative with conventional school systems and concludes that school performance is tied to decentralized management systems. Such analysis and discussions will lead to healthy debate (e.g., Howard and Preisman 2007) and an increased likelihood of more informed policy decisions.

This article recommends a partial merging of research agendas across diverse areas of organizational research to integrate the study of private and public interests using innovative theory and methods. In particular, we call for joint research that emphasizes the consequences of policy implementation for the interplay of public and private interests. The primary goal is to examine a range of subtle issues that reflect the connections among private and public institutions, behavior, and performance. The proposed agenda considers diversity in public interests, how public and private organizations align (or fail to align) their interests, how public and private behavior is shaped by the interaction between them, and how public and private interests merge and diverge dynamically.

Three observations are made here in support of this agenda. First, a range of institutional forms such as public-private partnerships and governmental subcontracting can be explored more deeply through integration of theories and methods used by scholars with diverse disciplinary backgrounds and research agendas. Some private corporations, foundations, and agencies are taking on responsibilities that previously were considered part of the public domain. Second, a large range of private actions have substantive consequences for the public. For example, many firms in low-income countries are locked into competitive disadvantages against rivals in high-income countries (Grabowski 1994). Third, a shift is occurring in societal expectations concerning the limitedliability corporation (McGahan 2007a). This institutional form, which was established in the 19th century, protects investors and managers from personal liability for actions they take as stewards of invested capital, provided that they do not act fraudulently or commit other crimes in the course of their duties. Social preferences for greater accountability are now calling into question this form of organization. Indeed, the concept of crime is being reconsidered and expanded to include "white-collar" and corporate offenses, such as infringements against the environment.

The following sections discuss (a) these three major new developments in public-private dynamics, which collectively illustrate the compelling need for new ways of thinking; (b) conceptual developments concerning private-public interactions that can guide further research; and (c) a proposal to adopt a new criterion called global sustainable value creation to integrate theory and serve as a modern welfare criterion for evaluating policies, actions, institutions, and context by both private and public actors. This concept involves considering strategies that promote intertemporal efficiency and economic value creation on a global scale. For example, on policies for addressing climate change, the criterion would involve analyzing objectives for achieving consummate performance (Williamson 1991) in environmental cleanliness over the long run and then aiming to achieve appropriate institutional and organizational configurations and actions that promote these objectives, given the current and probable future technologies for preserving the environment. We maintain that a focus on global sustainable value creation has important implications for organizations, institutions, incentives, competition, innovation, and global governance.

\section{Development \#1: Important Institutions that Merge Public and Private Interests}

Research on the connections between public and private interests has focused primarily on externalities and agency questions such as the following: When and how do private interests aggregate to a common interest? How should decision-making authority be allocated among individuals for the public good? How can externalities best be managed (Hart 1995b, Spulber 1989)? What determines the boundaries and the potential "optimal mix" between public and private in a mature market economy (Coase 1960, Hart 2003)? The public choice tradition has also raised questions about whether interests can be aggregated and goes so far as to suggest that the public interest may be a fictionalized construct in which public policy is shaped in negotiations among parties that pursue private interests (Buchanan and Tullock 1962, Mueller 2003, Stigler 1971).

The framing of these questions-and the implications both for public and business policy-has become limiting because institutions and organizations have formed 
that simultaneously reflect public and private interests (Ostrom 1990). Some of these institutions have existed for decades but have only recently become central to the public interest, and others have emerged recently. Examples include subcontracted military services (Avant 2005, Singer 2003, Baum and McGahan 2009), privatized prisons (McDonald 1990), and the Gates Foundation (Muraskin 2006), which is spearheading major initiatives to improve global health. The design of these organizations can be seen as endogenously determined by how public and private interests are defined and reconciled (Dunbar and Starbuck 2006).

Several areas of theory in related fields carry the potential to delve deeper into fundamental questions that reside in connections between public and private interests within these institutions. First, research in strategic management considers how decision makers in a particular situation interact to create, capture, and sustain economic value (Song et al. 2002). The development and application of transaction-costs theory in the context of public-private interactions can indicate how the framing of decisions to subcontract essential military services, for example, shapes the subsequent emergence of specialized capabilities (Baum and McGahan 2009). Property rights and agency theories assert that public-private partnerships can be further understood as emerging from inadequate private and public options for resolving incomplete contracting problems (Hart 2003, Martimort and Pouyet 2008).

Second, recent research on property rights considered from a resource-based view yields insights about how capabilities are created in the public and private interest and how these capabilities are owned and controlled (Foss and Foss 2005, Kim and Mahoney 2005). Consider the privatization of prisons, which has become increasingly prevalent in the past decade (Morris 2007). Privately owned firms compete for contracts on diverse activities such as prison construction, prisoner transportation, guard services, food and recreation management, and sanitation and janitorial services. Some companies act as general contractors and manage all these services. Through their normal course of business, companies develop competitive advantages based on accumulating capabilities. Are these developed capabilities privately or publicly owned? Once an initial contract expires, should the subcontracting state or federal government have property rights to appropriate these capabilities? Do these capabilities serve public or private interests or both? How can these capabilities best be sustained (Yang et al. 2008)?

Third, theories of agency relationships implemented in the context of a resource-based and capability-oriented view of institutional actors carry the potential to shed substantial light on governance and decision-making authority (Hambrick et al. 2008). For example, the Gates
Foundation has influenced the agenda for research concerning neglected diseases in public health. One of the priorities for the Foundation is sponsoring discoveries related to an HIV vaccine (Muraskin 2006). Imagine that a vaccine is discovered, perhaps in a University laboratory under grants from the Gates Foundation. How would property rights to the vaccine be governed? Many universities make partial claims on licensing rights (Argyres and Liebeskind 1998). The interests of the Foundation, of patients, and of local governments would be of central concern. Coordinating commitment of pharmaceutical companies, distributors, clinicians, and others in effective and efficient delivery of the vaccine could be enabled by thoughtful research into the consequences for public and private welfare.

In global public health, the failure of national and international public organizations (Easterly 2006) has led to intervention by the Gates Foundation. In turn, questions have been raised about whether this institution exacerbates market failures as well as resolves them in an interesting inversion of the public choice critique of the public sector. Is it in the public interest for the Gates Foundation to take such a large role in this effort? Many observers applaud the Foundation's involvement, yet the creation of economic value is in the interactions of the Foundation with others. The Foundation's purpose is to marshal resources in the interests of the public, but it is specific in its strategy about which members of the public should receive priority.

The large amount of resources concentrated on one disease can have important consequences for research on other major infectious diseases and even on health systems in resource-limited settings such as Haiti, where primary health has suffered in some instances despite the improvements in HIV care (Garrett 2007). By integrating the study of this type of institution, which is privately organized and managed, into the broader complex of public and private policy, we can learn from the precedent that it is setting and better understand the implications for complementary institutions, including private entrepreneurs and public policy bodies. The place to start would be in evaluating the existence and/or development of capabilities and their combination in ways that create more economic value than each involved organization can provide, develop, and leverage alone, as well as the potential side effects and the requisite governance structures that can help reduce any negative externalities. Although research in political economy (e.g., Shepsle and Weingast 1981) has dealt with game-theoretic facets of integrating private interests, less attention in this field has been on the administrative challenges of integration.

In sum, institutions and organizations shaped by both private and public interests are essential to achieve effective public and business policy. Agents acting in the public interest often have private agendas (Mueller 2006). Private interests do not aggregate in simple ways but also 
coevolve with public interests endogenously. Standard approaches emphasizing the tragedy of the commons and externalities analyses do not deal comprehensively with this endogeneity or with the central challenge of managing complex capabilities, which develop as private and public interests co-evolve.

\section{Development \#2: Private Actions with Implications for Public Welfare}

Private institutions, and the interests embedded in them, are often the initiators, instruments, and objectives of public policy. In the 1980s, the United States famously bailed out Chrysler (Luger 2000) and Continental Illinois National Bank and Trust (Stern and Feldman 2004), and in the 1990s, intervention by the federal government was essential to combat the instability created by the failure of Long-Term Capital Management, a hedge fund that could not cover its obligations (Lowenstein 2000). The savings and loan bailouts of 1989 (White 1991) and 1995 (Glasberg and Skidmore 1997) were tied to instances of fraud, malfeasance, and bad management. Enron and the corporate accounting scandals of the early 2000s rocked public confidence in even the largest and most established public corporations (McLean and Elkind 2003, Squires et al. 2003) and even sparked congressional hearings. As financial markets around the world reeled with failures in the subprime lending market (Argitis and Pitelis 2008, Stiglitz 2008), the initial stabilizing interventions were handled by Goldman Sachs, among others. This intervention, coordinated by the U.S. Federal Reserve, was designed in the public interest and was facilitated by Goldman Sachs' private action. These examples reveal the intertemporal character of public interests: effective intervention today may prevent the need for more substantial public intervention tomorrow.

The interplay between private and public interests dates back to the origins of sovereign government. What is new concerning these situations is (a) their salience, scale, and frequency (Lev 2003); (b) the complexity of responses to protect the public interest, and particularly the involvement of private organizations (such as Goldman Sachs in the sub-prime lending crisis) to protect public welfare; and (c) the extensive consequences of both private failures and public-private responses both as precedents for subsequent interventions and as acts that redistribute wealth.

By integrating the research agendas of business and public policy, a number of theoretical and empirical advances within organization science become possible. First, transdisciplinary integration carries the promise of promoting greater understanding of the leadership, reputational, and governance consequences of private and public actions. The benefits of such integration are now understood to be especially high in the wake of actions that can cause such damage to private interests that they reverberate into public problems. The nationalization of mortgage giants Freddie Mac and Fannie Mae and insurance giant AIG are cases in point.

Second, additional theoretical and empirical work is needed on public resources, including but not limited to financing, relationships, access, authority, and responsibility. What are the tradeoffs associated with allocating resources to rescue private corporations from insolvency? How should the capabilities that have accumulated within the rescued corporations be managed after public resources are used to develop them? Research is needed on the origins and emergence of public resources and on how they are deployed most effectively in the presence of complementarities with private capabilities. For example, how should the returns to a potentially valuable mine on public land be allocated and managed? Some authorities have noted that nonrenewable resources tend to be dramatically underpriced in private markets. Should governments intervene to ensure that these resources are priced to reflect their net present value? If so, how is this process managed, given that the political careers of those in authority are substantially shorter than the time horizons over which the resources retain their economic value?

Questions emerge about protecting the public interest when the complementarities between private and public resources are so strong that they create a moral hazard incentive among private parties to engage in excessive risk taking such as occurred during the subprime lending crisis (Demyanyk and Hemet 2008). How should private interests in public spaces be constrained? If subprime lenders extended credit under the belief that they would be bailed out, then are regulations failing? Is the public served by the refusal of protection to overextended borrowers? Are there any other forms of regulation that would be more effective than the promise of bailouts or that could help minimize the risk of potential future bailouts being required?

Third, the consequences of the depletion of public resources must be studied in a dynamic context. Because some public resources cannot be replenished (think of the long-run depletion of fossil fuels; McGahan 2009) or are depleted temporarily (the Fed cannot change the discount rate too frequently), public resources often must be valued intertemporally and by broader metrics than private resources. In particular, market valuations of public resources may fail for reasons extending beyond only contemporaneous externalities. The Stern Report (Stern 2008) is a useful step in this direction because it provides pecuniary estimates (shadow prices) of carbon (Hope 2008). Additional research is needed to obtain accurate economic valuations, decision metrics, control rights, and property allocations on a range of public resources (Barzel 1989, Kim and Mahoney 2002, Libecap 1989).

Finally, an improved understanding of risk taking is crucial for evaluating the intersection of public and private interests. Differences in risk tolerance and the scope 
of relevant uncertainty are central to effective decisions concerning how to manage events such as the subprime lending crisis. Institutional developments such as trading in derivatives, legitimized by public actions such as the Commodity Futures Modernization Act of 2000, enable private actions that have multifaceted consequences for the public interest (Hahn and Tetlock 2006). Institutional arrangements that reduce risk (Rosenberg and Birdzell 1986) and internalize the benefits and externalize the costs of private investments (North 1981) are critical determinants of economic development. In addition, public authorities often have responsibilities that shape risk and uncertainty for private actors. In certain cases, the public can take action that can create new areas of private activity. A case in point is the new carbon markets that have been created through government legislation (Convery et al. 2008). We need a better understanding of the extent to which private risks should be "internalized" by the public domain, as well as whether and when this internalization serves mutual interests. Thus, in the public domain, choices about managing the context for private risk also must also receive attention.

\section{Development \#3: The Limited Liability Corporation and the Public Interest}

The limited liability public corporation, established in the late 19th century, has become the centerpiece of research on private sector organizations. Executivemanaged, investor-owned, and publicly traded corporations constitute a significant part of the economy. By a recent estimate, more than 20,000 of these limited liability corporations exist and account for more than $15 \%$ of worldwide economic activity (McGahan and Porter 2003).

Yet many other forms of economic organizations exist. More than 3 million partnerships and registered proprietorships exist in the United States alone. Privately owned corporations that are not publicly traded-including those controlled by large privateequity firms - constitute a large and growing portion of economic activity. Nongovernmental agencies such as Oxfam, the American Red Cross, and Save the Children are major recipients of public aid and private charity (Black 1992, Gilbo 1987, Watson 2006). Charitable foundations, which are typically exempted from taxes in the public interest, fulfill their missions by dispersing funds through payments to private parties. Subcontractors with both tax-exempt and taxable status are central to military operations. Government expenditures constitute a large and growing proportion of economic activity. Outside the United States, governments have engendered institutional innovation that blurs the public-private boundary. China's Household Responsibility System, under which land belonging to the public is assigned to households, is an important case in point (Rodrik 2004). Corporate governance reforms in Japan designed to align private and public interests have fundamentally transformed the risks taken by businesses after the 1988 financial system crisis in that country (Yoshikawa et al. 2007).

To understand the nature and scope of economic activity, the agendas of organization scholars must be broadened to emphasize a wider range of institutions than the publicly traded, limited liability corporation (McGahan 2007a, 2007b). Management problems in private equity, nongovernmental institutions, private foundations, government agencies, and international institutions should be addressed by researchers from a range of disciplines. Solutions to market failures should be conceptualized in terms of hierarchies that take multiple forms rather than the principal form of the limited liability corporation (Williamson 1991). This proposed shift is not a matter of discontinuing study of corporations but, rather, a matter of rebalancing emphasis of organization research to consider returns on invested capital more comprehensively and more systematically. In addition, McGahan (2007a) maintains that organization scholars should deal with a much more diverse set of mechanisms for achieving returns on invested capital than what is available only through publicly traded corporations. The returns of large, public corporations have been influenced by the scale and scope of economic activity in other types of organizations and should be examined comprehensively.

Several major research opportunities arise from this agenda. First, the dissociation between private and public finance must be corrected. The two areas of activity are linked analytically under neoclassical assumptions of individual rationality (as suggested by "rational expectations" scholars; see Tobin 1980 for a critique) and are also tied because public financing depends on their effective administration through, for example, private banks and other financial institutions. Agency theory must be extended significantly to consider how the generation of new value-creating opportunities depends specifically on the interplay between public and private interests, as well as their respective differential capabilities for innovation and economic value creation. The consequences of new forms of financing and risk sharing such as hedge funds, private equity, and securitization for value creation must be evaluated in light of how the public interest evolves over time. The concurrent concentration of ownership and enhanced risktaking to generate higher returns in the short run may not be consistent with value creation over the long run (Dharwadkar et al. 2008).

Second, the emergence of alternative forms of economic organization raises questions about how resources are developed and allocated in a system that does not aim to maximize aggregate return on invested capital, but instead emphasizes maximizing the personal returns of specific investors. Research on the interplay between 
value creation and value capture is needed in this context. What are the consequences of different forms of organization for resource allocation and deployment? What kinds of resources are best deployed through different types of organizations? How can financial capital best be allocated into the hands of competent managers to create other forms of capital? What new forms of corporate organization may be effective for aligning public and private objectives?

Finally, broad questions arise concerning the nature of innovation and the roles of public institutions in the generation of knowledge in the modern economic environment. The Bayh-Dole Act, which generates private property rights to National Institutes of Healthsponsored research for private and quasipublic universities, represents a new form of wealth transfer that carries important consequences for economic incentives to innovate. Although excellent analysis has been done on this topic (e.g., Thursby and Thursby 2002), additional research on the nature and consequences of science-its scale, scope, locus, application, and potential commercializability-is needed to understand how property rights and decision authority evolves over time (Kaplan and Murray 2009). Parallel opportunities for research arise on other issues in public policy, education, public health, fine arts, medicine, law, and social sciences.

\section{Conceptual Opportunities on Public-Private Interactions}

New theory on public-private interactions also promises to generate insights concerning both business and public policy. We next consider (a) extending established theory, (b) bridging theories within organization science, (c) importing new problems into organization science from other fields, and (d) developing new theory and concepts.

\section{Extending Established Theory}

The first opportunity for advance is to extend current theories of the firm to address directly the interplay of private and public interests (Ostrom 1990). Because public interests are a function of the degree of alignment of private interests - and of mechanisms used to define the public interest in the absence of alignment-the interplay between private and public interests raises questions about individual differences and the ways common interests are framed. In particular, recent advances in organization science consider the sources and dynamics of change in the institutional environment. Additional research is needed on questions of framing, mechanism design, and the diversity of private interests (North 2005). Because private and public interests evolve over time, central questions arise about the robustness and veracity of interests in light of long-term commitments of resources to serve them.
The resource-based view (Barney 1991, Peteraf 1993, Wernerfelt 1984) has the potential to support policy makers in evaluating intertemporal implications of particular public investments that create new assets, which can take diverse forms and serve private interests differentially over time. For example, if greater public expenditures are allocated to cultivate specific skills in a population through publicly supported education and training, then a community may eventually excel internationally in an affected area; and the development of a public resource such as a marketplace or an information exchange may eventually create new opportunities in the public interest (Grabowski 1994, Rodrik 2004). Extending theory to address the interplay between private and public interests requires detailed investigation into the microdynamics of aggregation (Mayer and Argyres 2004).

\section{Bridging Theories within Organization Science}

A second area of opportunity is in the development of theory at the intersection of established areas of inquiry in the field. Organization science has established that the interplay between management and community interests is nuanced. When a firm develops a particular capability, some members of the public community may benefit significantly (e.g., the firm's customers or employees), although others are adversely affected (Donaldson and Preston 1995, Post et al. 2002). An important research agenda is to explore issues concerning whether and how business policy and public policy could be aligned and the extent to which and how organization science can contribute to this objective. A primary goal would be to better understand how public actions may differentially affect private interests and further how private actions may differentially affect public capabilities (Ostrom 1990, Spulber 1989).

In general, firms operate in an institutional and regulatory context that is heavily influenced by government (Shapiro and Taylor 1990, Rodrik 2004). Business policy often aims to adapt and/or shape this regulatory context, which may create concerns of regulatory capture (Mueller 2003, Posner 1974, Stigler 1971). Such concerns are typically based on a supposition that the interests of business and the public diverge. A rationale for this perspective is grounded in economics and goes at least as far back as Smith's (1776) dictum on conspiratorial tendencies by "people of the same trade" to raise and then maintain these higher prices- "collusion" in today's parlance. Is this view fully justified today? Can organization science research lead to different implications? How can we better understand public-private partnerships in the context of the tendencies for collusion to arise? Does government tend to promote monopoly when it engages with specific firms or industries (North 1991)? Is government more prone to failures than the market and/or to inducing market failures (Buchanan 
1986)? Can well-intentioned private actions lead to market and public failures? Is the public sector more prone to value-destroying, rent-seeking activities than the market (Krueger 1974)? When firms seek to be innovative through standardization or some other form of direct interaction, are their interests aligned with those of the public? This agenda must begin with a clearer conceptualization of public interests, activities, organizations, and institutions than has currently been implemented in much of the research in the field.

Over the past 30 years, a substantial literature in organizational economics has become influential in organization science. Leading figures in economics-Coase $(1960,1988)$ and Williamson $(1985,1996)$ in transaction costs theory; Hart (1995a, 2003) and North (1990, 2005) in property rights theory; Arrow (1985) and Jensen (1983) in agency theory; Penrose (1959) and Teece (1982) in resource-based research; and Schumpeter (1934) and Nelson and Winter (1982) in evolutionary economics - have contributed to organization science by contemporaneously considering both business and public policy.

The implications of these theories for business policy have been extensively explored (Mahoney 2005). However, the public policy implications of these theories have received less attention. In particular, given that no absolute definition of the public interest is possible, and given that all public policy serves some private interests over others, then business and public policy may be entirely interdependent. This interdependency deserves substantially more research. What can we learn, for example, about the implications of the process of privatization (of many types of organizations such as prisons) for community welfare? More research is needed to obtain satisfactory answers to this question. Business policy has emphasized Coase's (1937) transactional work on the nature of the firm, but has not fully incorporated Coase's later work (1960) on the relationships between the social costs (e.g., the negative externality byproducts) of investing in particular goods in the context of positive transaction costs and its far-reaching implications for law and public policy. In a world of zero transaction costs, legal liability would not matter for economic efficiency-the so-called "Coase Theorem" (1960) — whereas in a world of positive transaction costs, liability rules can matter greatly for economic efficiency (Dahlman 1979). In the case of privatization, asymmetric information and positive transaction costs may mean that the most appropriate private actor may not win contracts on government business. This result is but one of many potential instances and outcomes of "rent seeking" (Krueger 1974, Tullock 1989).

An opportunity exists for further application of property rights theory to the understanding of public-private partnerships as contracts (Hart 2003) and to the identification of conditions under which these partnerships emerge optimally (Martimort and Pouyet 2008). Furthermore, opportunities continue to arise for integrating into economic theory the strategic implications of market failure, heterogeneous firms, and imperfect competition (Baumol 1991, Helfat et al. 2007, Teece 2007, Teece et al. 1997). Endogenous growth theories (Lucas 1988, Romer 1986) acknowledge such concerns for policy yet do not explicitly incorporate the strategic responses of firms with diverse capabilities and activities into policy prescriptions. Our collective understanding can be enhanced by exploring the implications of recent advances in organization policy on public policy.

Policies that are designed to regulate firm behavior would be better informed by management research. A prominent example of the potential for insight arises from the work of Edith Penrose, often credited as the seminal author in the resource-based view. Penrose (1959) claimed that even if a process of growth is efficient, the large sizes of firms that may emerge as stewards of crucial resources may lead to inefficient monopolistic market practices. The implication, evocative of a Schumpeterian process of creative destruction (Foster and Kaplan 2001), is that government should aim to balance the promotion of innovative practices with their potential consequences for ex post monopolistic practices, by, for example, devising policies and institutional configurations that favor perennial innovation and a level playing field.

Research at the intersection of business and public policy could address such questions as how we should structure public-private contracts to promote the emergence and development of new capabilities while diluting the prospect of ex post monopoly. The objective of this new area of policy studies is to cultivate innovation and creativity along the lines of Penrose (1959) to support a process of sustainable wealth creation (Pitelis 2007a).

\section{Importing Problems into Organization Science from Other Fields}

Insights from organization science have been applied to several problems that have traditionally been dealt with most effectively in other fields. For example, Jorde and Teece (1990) apply and develop important management and resource-based insights concerning intertemporal efficiency, cooperation, innovation, and their interactions. This analysis calls for changes in U.S. antitrust legislation to account for the positive welfare implications of noncollusive interfirm cooperation over innovation. Recent advances on issues of competitiveness, such as Porter's (1990) "diamond model," which emphasizes the role of industrial clusters and public-private partnerships, resonate with Schumpeterian and resource-based views (Foster and Kaplan 2001, Pitelis 2007b). Although these approaches often involve elements of both public and business policy, the interaction between the two has yet to be fully explored. 


\section{Developing New Theory and Concepts}

A final area of opportunity for conceptual development is new constructs, concepts, and theories for investigating interrelationships between private and public interests. Opportunities in this area are extensive and reflect new research at multiple levels of analysis. Microbehavioral research on the structure of private interests promises to yield insight about alternative mechanisms for their aggregation into community, sovereign, and global interests. Macrobehavioral analysis investigating the mechanisms by which individuals express, balance, and advocate their interests can generate insights about the dynamics of public interests. Structural analysis on how public interests are integrated over time promises to yield insights on both their foundations and policy implications. Finally, new macrosocial concepts carry promise for expressing, understanding, and analyzing the interdependence of public and private interests.

\section{The Integrative Concept of Global Sustainable Value Creation}

The examples discussed in the previous sections considered the interface of business and public policy and the opportunities for research in theory and empirics. To illustrate the potential for insights, this section briefly discusses a new concept called global sustainable value creation (Pitelis 2007b), defined below.

One salient conceptual lens for analyzing public policy is industrial organization, a branch of economics. Two basic premises of the industrial organization paradigm are that firms seek to maximize economic profits and that governmental bodies may correct market imperfections (Scherer and Ross 1990, Tirole 1988). For example, the pursuit of economic value capture through restrictive practices by firms can hinder efficient resource allocation, leading to the need for government intervention. According to this approach, antitrust policies should aim to effect industry structures with strong productive and allocative efficiency.

A facet of this view is that it focuses on static allocative efficiency rather than on intertemporal innovative efficiency (Kaldor 1972). In particular, innovation is not centrally addressed in the neoclassical economic model (Baumol 1991). As noted by Schumpeter (1942), Penrose (1959), and Nelson and Winter (2002), once intertemporal or dynamic efficiency-and thus economic value creation through innovation-is considered, then a range of oligopolistic and even monopolistic industry structures may be superior to perfect competition and contestable markets for innovation and dynamic efficiency (Aghion and Howitt 1998, Sutton 1998).

In an early effort to account for both noncollusive cooperative arrangements between firms and innovation (in its interrelationship with interfirm cooperation), Jorde and Teece (1990) called for changes to U.S. antitrust policies to account for the dynamic efficiencies of such arrangements. "Systems of innovation" approaches (De la Mothe and Paquet 1996, Freeman 1988, Lundvall 1992, Nelson 1993) point to public-private partnerships and the wider organizational and institutional nexus around firms that promotes innovation, economic value creation, and competitiveness (Aiginger 2006). Such a nexus can include industrial clusters, public-private partnerships, social capital, nongovernmental organizations (NGOs), and other nonpublic, nonprivate organizations.

Until recently, the field of industrial organization has focused on evaluating interfirm cooperation primarily as collusion and principally as price collusion. As noted by Richardson (1972), however, interfirm cooperation may also have efficiency implications. This idea is explicit in Porter (1998) and subsequent analyses of networks and clusters (Bell and Zaheer 2007). The "systems of innovation" approach to public policy is a potent alternative to the market structure-oriented approach of neoclassical economics and is currently receiving attention by policymakers in Europe (Pitelis 2007b). Yet despite its substantial merits, this perspective falls short of providing a comprehensive framework for addressing the relations between public and private interests, especially for the purposes of organization science scholars, for at least three reasons. First, the systems perspective (as well as Penrose 1959 and the resource-based view as a whole) do not yet account for agency issues that arise from the nature, role, and significance of divergent economic interests and for related problems of "collective action" (Olson 1971). The systems view emphasizes the benefits of innovation by nations, regions, and sectors (Fagerberg et al. 2005). However, potentially divergent interests within firms, networks, regions, and nations can be important in determining both the character and direction of innovation (Cyert and March 1963, Gottschalg and Zollo 2007, Gupta et al. 2007, Pitelis 2007a, Rothaermel and Hess 2007). As Lundvall, a protagonist of the approach, observes, "The concept was intended to help develop an alternative analytical framework to standard economics and to criticize its neglect of dynamic processes related to innovation and learning when analyzing economic growth and economic development" (2007, p. 96).

A second limitation of the systems perspective concerns the sustainability of value creation. Sustainability is a condition satisfied when agents, acting in their shortrun self-interest, do not undermine their own long-run interests or the interests of successive generations of economic actors (Lenox 2006). Sustainable actions may not yield net intertemporal systemic economic benefits (i.e., there is no guarantee that innovations will not generate first-mover advantages, dominant positions, restricted entry, or stemmed forces of "creative destruction," which subvert long-term efficiency). In this context, a focus on firm-level innovation is not adequate by itself to ensure 
sustainability (Murray and O'Mahony 2007, Rothaermel and Hess 2007).

A third problem with the "systems of innovation" view is that it focuses principally on the nation state. However, nation states may hinder the process of global value creation if they pursue narrow interests in, for example, strategic trade policies that undermine the value-creating capabilities of firms in less-developed countries (Grabowski 1994, Stiglitz 1989). With few notable exceptions (Nelson 2007, Nelson and Winter 2002), the systems perspective shares with industrial organization economics a focus on the nation and does not emphasize how firms and nations may restrain competition (and trade) intertemporally and thereby undermine sustainability.

The limitations of the systems approach are recognized: "The need for a change in theoretical foundations and for a new paradigm for designing public policy has not yet been fulfilled" (Lundvall 2007, p. 97). Lundvall (2007) proposes more emphasis on issues of distribution of power, institution building, and the openness of innovation systems. All of these issues, we maintain, are integral to and can be addressed through the concept of global sustainable value creation. We therefore propose that the criterion of global sustainable value creation is enacted to diagnose and evaluate the consequences of economic activities for private and public welfare. As an economic construct, total economic value created equals the sum of consumer and producer surplus at a given point in time. A focus on innovation allows for the fact that investment may over time increase consumer welfare as well as producer surplus. Global sustainable value creation also accounts for externalities and restrictive practices and thus considers a broader context than is the norm in research on industrial organization.

The purpose of introducing this criterion into the vocabulary of researchers is to cultivate an understanding of the linkages between individual and business activity at one place and time with interests that may arise in other places and in the future. The word "global" draws attention to the world community rather than to the interests of sovereign states, businesses, or local communities. "Sustainability" points to the intertemporal nature of the linkages between actions. "Value creation" is intended in the sense of Brandenburger and Stuart (1996) to account for both the benefits and costs of activities (i.e., some opportunities for impact may generate great benefits but may be too costly to implement effectively).

This criterion is not unique in its focus on the creation of value or on sustainability per se. The need for a new welfare criterion arises from the complex interactions between private and public actors that unfold over time. Time inconsistency problems - what seems right in the short run may prove wrong in the longer run-can arise from bounded rationality, simple mistakes, or divergent interests that change over time (Tirole 1988). The need for interest alignment is crucial in general and is of interest to organization science scholars in particular. This criterion allows for study of evolving, interacting interests within organizations (Cyert and March 1963, Gottschalg and Zollo 2007, Pitelis 2007a) and between organizations, among individuals, and across governments (Hirschman 1982, North 1981, Olson 1971).

An emphasis on sustainability reflects the view that the pursuit of individual interest sometimes undermines systemic interests and may undermine the achievement of individual self-interest in a subsequent period. Consider, for example, two types of relationships that are particularly difficult to analyze comprehensively using the industrial organization and systems of innovation perspectives: firm national and national global.

Sustainable competitive advantages in firms do not always serve the national interest. When firms achieve competitive advantages through restrictive practices, they may undermine the sustainability of nationwide value creation by constraining competition, innovation, and learning. This idea has been explored extensively in the industrial organization research literature. For example, Microsoft has been fined by regulatory authorities for restricting competition. The emphasis under the criterion of global sustainable value creation is on the implications of restricted competition on dynamic efficiency. Even when firms achieve competitive advantages through innovation, the risk is present that they may resort to restrictive practices. In this context, public policy is required to sustain the process of economic value creation by facilitating perennial innovation through a level playing field and support to small and mediumsized enterprises in order that competition not be subverted (Penrose 1959).

More generally, firms understandably engage in political activities when they are highly dependent on government regulation or contracts for economic survival; under such conditions, the subversion of competition may be likely when there are large firms operating in more concentrated industries (Bonardi et al. 2005). Indeed, it is well documented empirically that firmspecific benefits result from political strategies (Hillman et al. 1999, 2004). On the one hand, strategic political management over time can be considered a dynamic capability and a source of value creation (Oliver and Holzinger 2008). But from a resource-based view, firms compete in strategic factor markets and political markets not only to access economically valuable resources for themselves but also to exert control over their competitors' resources (Capron and Chatain 2008, Schuler et al. 2002). Furthermore, strategic insight can be gained from treating political markets as a type of strategic factor market (Maritan and Florence 2008). 
On the other hand, as noted by the "public choice" school of analysis (Mueller 2006), national policies may be captured by private interests and may reflect collusion between firms and their governments for mutual gain (Hillman and Hitt 1999, Olson 1971, North 1991). Possibilities of regulatory capture (Posner 1974, Stigler 1971) call for pluralism of institutional and organizational structures that provide checks and balances to promote sustainability such as through NGOs, consumer associations, firm clusters, clubs, associations, and "social capital" (Moran and Ghoshal 1999, Nelson 2007, Putnam 1993). These organizational and institutional structures emerge and develop endogenously with the interests that they seek to monitor. In some documented instances, they fail to ensure sustainability given the potential incentives for firms and nations to maximize the surplus accrued to them, and the panoply of means and policies that large firms and developed nations have at their disposal (Ramamurti 2004).

Additional research is essential for one to better understand these failures and the role of extant and potentially embedded power structures and how these failures can be addressed. The global financial crisis is adding credence and urgency to this need. In contrast, the criterion of global sustainable value creation suggests that protectionism by developing countries in critical industries may promote economic welfare by infusing competition, innovation, and learning into the system (Nelson 2007, Pitelis 2004).

Differential treatment of developed and developing economies is an immediate corollary to the global sustainable value-creation construct and is predicated not on grounds of fairness but on grounds of economic efficiency. Strategic trade policies developed under global sustainable value creation call for institutional and organizational configurations that account for global rather than only national interests. Academic research using this construct is essential because practicing organizations previously charged with responsibility for considering global interests have sometimes failed. For example, research on the World Trade Organization and others show that such organizations are not immune to "capture" (Bhagwati 2005, Ramamurti 2004). The complex interrelationships among global governance, national policy, and business policy (Pitelis 2009, Yoshikawa et al. 2007) mean that this research is imperative.

A focus on global sustainable value creation raises new questions concerning the interaction between business policies and the interests of individuals, nations, regions, and other economic actors. Sustainability raises "strategic contradictions" (Smith and Tushman 2005) such as cooperation without collusion, the avoidance of restrictive practices, and the intersection of shortterm efficiency and innovative efficiency. Better policy depends on deeper research into the complex implications of actors, actions, and initiatives such as privatized prisons, quasipublic agencies, and strategic trade policies (Krugman and Smith 1994).

The concept of global sustainable value creation may yield insight about opportunities for collective action that cannot be readily implemented in a practical sense. One major problem is in the possibility of identifying a public interest. Arrow's (1951) Impossibility Theorem demonstrates that, with as few as three discrete alternatives, there is no voting procedure that can convert the ranked preferences of individuals into a community-wide ranking system while simultaneously meeting reasonable distributive and fairness criteria such as unrestricted domain, nonimposition, Pareto efficiency, nondictatorship, and the independence of irrelevant alternatives (Arrow 1951, Sen 1970).

In addition, global sustainable value creation is predicated on knowledge about the actors, actions, and policies that promote worldwide sustainability of value creation, which requires a high degree of rationality and learning. It is for this reason that our emphasis is on institutional and organization configurations that diagnose, transfer, and create knowledge and learning (Argote 1999, Rodrik 2004). We also recognize that, even if the global sustainability objective is adopted, the implementation of appropriate policies may be impeded by collective action and prisoner's dilemma problems (Kapur 2002), as well as challenges of asymmetric information and limited or absent information and coordination (Hausmann et al. 2008).

Collective action can arise whenever it is in the interest of a (usually small) powerful group to thwart change that is inimical to its short-term interests (Olson 1971). Prisoner's dilemma problems involve situations where the pursuit of agents' self-interest leads to actions that fail to promote the joint interests of the parties involved, even when these agents are aware that more beneficial actions are available (Libecap 1989). Absent and limited information by the public sector, the private sector, or both, as well as coordination failures between private agents point to the need for public-private interactions to acquire information and to public intervention to solve market failure-engendering coordination failures (Ostrom 1990). In this context, the role of government should be to liaise with the private sector without being captured by it (Rodrik 2004). Overall, the research literature on the hazards of "capture" focus on market failures at the national level without identifying optimal levels of behavior at the global level.

Global sustainable value creation requires the conceptualization of international collective goods. Such goods can be organized by hegemonic powers (Kindleberger 1986) or within systems that are organizationally and institutionally diverse (Moran and Ghoshal 1999). Despite the benefits of centralization for speedier decision-making and coordination, even enlightened hegemony is subject to important limitations such as an 
incentive to allocate monopoly rights (North 1990). Yet systems cannot provide international collective goods such as global safety-they can simply help guard against hazards in their dispensation by states and international organizations. In addition, systems can enable collective goods and their sustainability. Global sustainable value creation as a construct yields a benchmark for enlightened private and public interests and may even ultimately serve to deter hegemonic capture and system failure. This diversity and procedural rationality-based approach is in line with organization science (Cyert and March 1963, Simon 1995) and pluralist theories in political science (Lively 1978, Vincent 1987).

An example of a public-private interaction that could be explained and predicted by our focus on global sustainability, but not by other perspectives, is the Gates Foundation. This case involves enlightened behavior by the private sector, motivated by global sustainability concerns and bringing in the public sector to leverage respective advantages to achieve a purpose. Such behavior is difficult to explain, in terms of narrow rational utility maximization (the industrial organization view) or the national interest (the systems view). A focus on global sustainability helps explain this purpose. At the same time, the potential distortion that can be created when the public sector and its role are taken over by private players calls for pluralism and diversity that help create checks and balances through mutual monitoring and bonding.

A focus on global sustainable value creation enacted through pluralism and diversity could have helped avoid the current problems of the global financial markets. These problems are arguably the result of a neglect of sustainability and embedded power structures, an exclusive focus on short-term interest, a belief that markets are entirely self-regulating, and even financial hypocrisy (Stiglitz 2007). As Stiglitz (2007) noted, during the East Asian crisis, free market advocates advised East Asian governments not to bail out their troubled financial institutions, so as not to distort market signals and create moral hazard problems. Adherents of such views, however, more recently were quick to identify systemic benefits of the proposed bailouts of U.S. financial institutions. In addition, other Western institutions spotted the opportunity to buy East Asian companies inexpensively and even made provisions not to pay taxes, when/if they sold the companies back to domestic actors. The hypocrisy is in first rejecting intervention as unnecessary and distorting in one situation, and then embracing intervention in another. Such hypocrisy does not aid the global leadership role of American institutions, such as the World Bank and the International Monetary Fund (Stiglitz 2007).

A focus on sustainability by regulators, NGOs, and enlightened business leaders could help restrain the greed and excesses that led to the current crisis. These include the extensive reliance on shareholder value (at the neglect of other socioeconomic stakeholders) and/or wider sociopolitical considerations, such as distributional (Argitis and Pitelis 2001) and environmental considerations that help foster sustainability. Sustainabilitypromoting regulation, calls, and actions by NGOs and consumer associations and less recklessly aggressive behavior by business leaders would help avert "innovations" that delink lending from risk taking (as in the case of derivative products) and link executive pay to longer-term economic value creation, fostered by longerterm investments and innovations-not simply shortterm share valuations (Lazonick and O'Sullivan 1996). The worldwide dimensions of the crisis are a powerful reminder that we are all in the same boat and that sustainability is key.

A nonexhaustive list of research areas emanating from a focus on global sustainable value creation, include the following:

- Sustainability at varying levels of analysis-An indepth analysis of the interaction between firm-level, nationwide, and global sustainable competitive advantages, including the very redefinition of these concepts, to take into account their interactions and longer-term socioeconomic or environmental implications. For example, how sustainable is so-called sustainable competitive advantage (the major focus of strategic management research) when its pursuit fails to foster national and global value creation, creates sociopolitical tensions (e.g., through dramatic increases in inequalities), depletes nonrenewable resources, or all of the above? How best could firms join firm-level competitive advantages with nationwide and global sustainable value creation (e.g., by internalizing the effects of their actions on the environment, sociopolitical stability, or both)?

- Public and private governance-An in-depth analysis of the interaction between corporate, public, and global governance (Hambrick et al. 2008) and the identification of the respective differential capabilities of each, as well as the appropriate mix that helps foster sustainability. If, for example, corporations are best in economic value creation, governments in providing the rules of the game (institutional setting) and legitimacy, and NGOs in promoting social capital and cohesion (Klein et al. 2009), how could we best leverage these respective capabilities/advantages to promote sustainability? How can we (re-)structure existing national and international organizations to foster global sustainable value creation?

- Value creation and the allocation of value-An identification of win-win actions by business, public, and international actors (such as the promotion of clean energy by the Danish government), as well as cases of win-lose (where, e.g., subsidies for green energy disadvantage conventional energy producers) and identification of policies that help resolve any resulting 
Table 1 Three Views on Sustainable Value Creation

\begin{tabular}{|c|c|c|c|}
\hline & $\begin{array}{c}\text { Neoclassical industrial } \\
\text { organization }\end{array}$ & $\begin{array}{c}\text { Traditional systems of } \\
\text { innovation }\end{array}$ & $\begin{array}{c}\text { Global sustainable } \\
\text { value creation }\end{array}$ \\
\hline Welfare criterion & $\begin{array}{l}\text { Value creation through the } \\
\text { efficient allocation of scarce } \\
\text { resources; emphasis on the } \\
\text { industry and nationwide } \\
\text { consumer surplus as measure } \\
\text { of "welfare" }\end{array}$ & $\begin{array}{l}\text { Economic value creation through } \\
\text { intertemporal innovation-induced } \\
\text { efficiency and knowledge-resource } \\
\text { creation; emphasis on nationwide } \\
\text { wealth creation as a measure of } \\
\text { welfare }\end{array}$ & $\begin{array}{l}\text { Global sustainable value creation } \\
\text { through allocative and intertemporal } \\
\text { innovation-induced efficiency and } \\
\text { knowledge-resource creation; } \\
\text { worldwide sustainable wealth } \\
\text { creation is the new criterion of } \\
\text { "welfare" }\end{array}$ \\
\hline Modality & $\begin{array}{l}\text { Optimal market structures such } \\
\text { as perfect competition or } \\
\text { perfect contestability; recent } \\
\text { recognition of more nuanced } \\
\text { relationship between industry } \\
\text { concentration and innovation }\end{array}$ & $\begin{array}{l}\text { Innovation-promoting institutions, } \\
\text { organizations, and policies, systemic } \\
\text { interactions }\end{array}$ & $\begin{array}{l}\text { Sustainability promoting governance } \\
\text { through markets, firms (intra- and } \\
\text { international), agencies, and } \\
\text { systemic interactions }\end{array}$ \\
\hline $\begin{array}{l}\text { Conflict and } \\
\text { agency }\end{array}$ & $\begin{array}{l}\text { Economic interactions } \\
\text { addressed through economic } \\
\text { bonding and monitoring, } \\
\text { incentives, and sanctions. No } \\
\text { wider interactions considered }\end{array}$ & $\begin{array}{l}\text { For the majority of the systems of } \\
\text { innovation literature, issues of conflict } \\
\text { and agency are nonexistent, at the } \\
\text { firm or economy-wide level. }\end{array}$ & $\begin{array}{l}\text { Present at firm, national, and global } \\
\text { levels-multiple "agencies"; } \\
\text { addressed through system } \\
\text { interactions and a focus on } \\
\text { sustainable global value creation } \\
\text { effected through pluralism, diversity, } \\
\text { mutual monitoring, and bonding }\end{array}$ \\
\hline
\end{tabular}

conflicts, so as to foster sustainability. Interesting questions include the extent to which the bailout of automobile producers by the Obama administration is good for socioeconomic and environmental sustainability (by, e.g., disadvantaging more efficient non-U.S. producers and/or by failing to promote cleaner-technology cars), and if it is, how could public resources best be leveraged to foster global sustainable value creation.

These are challenging questions, not least because they involve global corporations as well as national government and bailouts. Such bailouts of UK global financial institutions are already costing the UK government up to $20 \%$ of its GDP. Should such global institutions be bailed out by the global community? Is the extant global governance structure in a position to respond to these issues with an eye to fostering sustainability? If not, how could it be restructured to do so?

Our intent in introducing the concept of global sustainable value creation is not to create an actionable policy agenda immediately, but rather to unleash efforts and attention on the most pressing collective problems of our time. The concept of global sustainable value creation is an archetype that draws attention to the urgency of global sustainability problems. It is precisely because the research and action agenda is so complex that we must get started.

Implementing this agenda will require overcoming barriers that make it difficult for organization scholarship to consider an integrative agenda. However, these barriers are not insurmountable. For example, teachers of public policy and strategic management often use an industrial organization perspective to explain the neoclassical "welfare loss of monopoly power" approach to public policy (Tirole 1988 and Table 1). We maintain that resources should be leveraged from organization science scholars to expand these approaches-not least because continuing reliance on conventional welfare criteria borrowed from the economics discipline yields incomplete insights about the efficacy of public policy for both public and private welfare and intra- and internationally.

\section{Implications and Concluding Remarks}

Table 1 compares global sustainable value creation as an alternative and complementary criterion to the perspectives promoted under neoclassical industrial organization and the traditional "systems of innovation" views. The crucial insight offered under the global sustainable value-creation view is that the benefits and costs of innovation are essentially tied to the interests of both private and public parties within nations and internationally; that these interests may change over time in complex ways; and that interest alignment is crucial in promoting global, as opposed to localized, interests.

The comprehensive analysis by Walsh et al. (2003) of empirical research in the Journal of Management concludes that the public interest and the social objectives that were supposed to stand alongside economic objectives in orienting the work of management scholars have been misplaced and as a field we need to rebalance our focus. The central tenet of this paper is to affirm the need for rebalancing. We have also endeavoured to identify steps toward a new framework that may facilitate progress.

Recent cases of public-private interactions point to issues and considerations that are difficult to analyze 
Table 2 Major Research Opportunities on Public and Private Interactions in the Fields of Organization Science, Entrepreneurship, and Management

\begin{tabular}{|c|c|c|}
\hline & Theoretical & Empirical \\
\hline \multicolumn{3}{|l|}{ Individual interests } \\
\hline $\begin{array}{l}\text { Aggregation to the } \\
\text { public interest }\end{array}$ & $\begin{array}{l}\text { How can private interests be identified and } \\
\text { assessed? How can we compare between } \\
\text { different "welfare criteria"? }\end{array}$ & $\begin{array}{l}\text { How can the public interest be measured and the } \\
\text { fulfilment of interests assessed? How can we } \\
\text { operationalize different "welfare criteria"? }\end{array}$ \\
\hline $\begin{array}{l}\text { Facets of interests and } \\
\text { changes over time }\end{array}$ & $\begin{array}{l}\text { How can competing and complementary facets } \\
\text { of private interests best be considered and } \\
\text { aligned? }\end{array}$ & $\begin{array}{l}\text { What are principal instances and major case } \\
\text { studies of complex and evolving interests? }\end{array}$ \\
\hline \multicolumn{3}{|l|}{ Organizations } \\
\hline \multirow[t]{3}{*}{ Corporations } & $\begin{array}{l}\text { How and when can private corporations organize } \\
\text { to satisfy public interests? }\end{array}$ & $\begin{array}{l}\text { Do corporations perform systematically better or } \\
\text { worse than the norm when they pursue public } \\
\text { interests? }\end{array}$ \\
\hline & $\begin{array}{l}\text { Are private corporations prone to systematic } \\
\text { underinvestment in the pursuit of public } \\
\text { interests? }\end{array}$ & $\begin{array}{l}\text { Are corporations innovative when they pursue } \\
\text { public interests? Are they quicker than } \\
\text { nonprivate organizations to adapt to changes } \\
\text { in the alignment of interests? }\end{array}$ \\
\hline & $\begin{array}{l}\text { Do corporations regularly "capture" public } \\
\text { interests and influence them for private gain? }\end{array}$ & $\begin{array}{c}\text { How have governments performed in creating } \\
\text { and capturing value in the public interest? }\end{array}$ \\
\hline \multicolumn{3}{|l|}{ Government agencies } \\
\hline & $\begin{array}{l}\text { What constitutes entrepreneurship in the public } \\
\text { sector? What are the levels and characteristics } \\
\text { of effective and ineffective public } \\
\text { entrepreneurship? }\end{array}$ & $\begin{array}{l}\text { What are the major impediments to the promotion } \\
\text { of global sustainable value creation within } \\
\text { individual agencies? }\end{array}$ \\
\hline & $\begin{array}{l}\text { How can government agencies best assess and } \\
\text { balance the interests of diverse constituents in } \\
\text { the public interest? Are public-private } \\
\text { partnerships the principal collaborative } \\
\text { mechanism? What other mechanisms are } \\
\text { available? }\end{array}$ & $\begin{array}{l}\text { What exemplars of global sustainable value } \\
\text { creation have emerged in the public sector? }\end{array}$ \\
\hline \multicolumn{3}{|l|}{ Countries } \\
\hline & $\begin{array}{l}\text { What are the implications of global sustainable } \\
\text { value creation for public policy within and } \\
\text { across countries? }\end{array}$ & $\begin{array}{l}\text { For which countries and periods of time has } \\
\text { global sustainable value creation been } \\
\text { greatest? }\end{array}$ \\
\hline & $\begin{array}{l}\text { How have countries promoted and achieved } \\
\text { global sustainable value creation? What } \\
\text { impedes value creation at this level? }\end{array}$ & $\begin{array}{l}\text { How have countries succeeded and failed in } \\
\text { cooperating to achieve global sustainable } \\
\text { value creation? }\end{array}$ \\
\hline
\end{tabular}

fully with the traditional tools of neoclassical industrial organization or of systems of innovation views. Despite the important progress achieved under each of these views, an opportunity arises for deeper investigation of the misaligned and divergent interests of economic agents and of the consequences for global sustainable value creation. The new perspective is needed to advance understanding of the endogenous evolution of public policy, pluralism, and global governance-three important issues in organization science. A focus on global sustainable value creation helps explain, predict, and prescribe good managerial practice, public policy, and global governance.

The proposed framework also has important limitations. Progress depends on integrating different areas of organization science (e.g., agency theory, behavioral theory, dynamic capabilities, game theory, institutionalization theory, organizational learning theory, property rights theory, real options, resource-based theory, systems of innovation, and transaction costs theory) conceptually, formally (mathematically), and empirically. Current knowledge falls short of building an evolving science of organization that contributes systematically to global sustainable value creation.

The statistician Tukey wrote that it is "far better [to offer] an approximate answer to the right question, which is often vague, than an exact answer to the wrong question, which can always be made more precise" (Tukey 1962, pp. 13-14). The most important questions in organization science are theoretically difficult and resistant to empirical analysis. However, the stakes are simply too high to avoid taking risks within the evolving science of organization (Mahoney and McGahan 2007). The time has come to do better.

This paper describes several opportunities for further research to accomplish this objective. First, we identify a number of important phenomena that relate to the interplay between private and public interests, including 
the emergence of public-private institutions, such as the Gates Foundation; the salience and frequency of private actions with public consequence, such as in the current financial crisis; and the fragility and bluntness of old governance mechanisms such as the limited liability corporation as flagship mechanisms at the interface of private and public interests. Organizational researchers with diverse lenses on these phenomena, using established theory, have the potential to inform both private business and public policy that are intended to intervene and shape responses at multiple levels.

Second, we identify several crucial opportunities for the development of theories by organizational researchers. These opportunities include extending current theory under the institutional, resource-based, and regulatory (industrial organization) perspectives to inform analysis of the interdependence of private and public interests (Aguilera et al. 2008). We also suggest bridging established theories to define new theories, concepts, and constructs for understanding organizational phenomena. Yet another opportunity for theoretical development concerns the introduction of new problems of organization of the relationships between private and public interests (Nickerson and Zenger 2006). We also advocate development of new constructs, concepts, and theories for interpreting relationships between private and public interests, and particularly the application of multilevel analysis for generating insight in this area.

Finally, we explain and explore the concept of global sustainable value creation as an important construct for assessing public interests and their relationship to private interests. This concept is an important complement to the classical and neoclassical concepts of allocative and intertemporal efficiency because it incorporates externalities, allows for dynamic efficiencies and inefficiencies, and provides for the hard-to-quantify interests of currently disenfranchised actors. Further research is needed to develop methods for applying this concept empirically and in practice, and for refinements for dealing with the range of nuanced problems associated with definitions of interests and with their aggregation. Table 2 outlines some additional research opportunities that arise from our perspective and focus, which we intend to pursue and hope to motivate others to do as well.

\section{Acknowledgments}

The authors thank Editor-in-Chief Linda Argote, two anonymous reviewers, Don Hambrick, Jeanne Connell, Peter Klein, Yasemin Kor, Cathy Maritan, Mike Prietula, Annalisa Savaresi, and Deepak Somaya for helpful comments and suggestions on earlier drafts of the paper. The usual disclaimer applies.

\section{References}

Academy of Management Journal 2005. [Special topic forum on public policy]. 48(6).
Aghion, P., P. W. Howitt. 1998. Endogenous Growth Theory. MIT Press, Cambridge, MA.

Aguilera, R. V., I. Filatotchev, H. Gospel, G. Jackson. 2008. An organizational approach to comparative corporate governance: Costs, contingencies, and complementarities. Organ. Sci. 19(3) 475-492.

Aiginger, K. 2006. Revisiting an evasive concept: Introduction to the special issue on competitiveness. J. Indust., Competition Trade 6(2) 63-66.

Argitis, G., C. Pitelis. 2001. Monetary policy and the distribution of income: Evidence for the United States and the United Kingdom. J. Post-Keynesian Econom. 23(4) 617-638.

Argitis, G., C. Pitelis. 2008. Global finance and systemic instability. Contributions to Political Econom [Special issue on global finance] 27(1) 1-11.

Argote, L. 1999. Organizational Learning: Creating, Retaining, and Transferring Knowledge. Kluwer Academic Publishers, Norwell, MA.

Argyres, N. S., J. P. Liebeskind. 1998. Privatizing the intellectual commons: Universities and the commercialization of biotechnology. J. Econom. Behav. Organ. 35(4) 427-454.

Arrow, K. J. 1951. Social Choice and Individual Values. John Wiley $\&$ Sons, New York.

Arrow, K. J. 1985. The economics of agency. J. W. Pratt, R. J. Zeckhauser, eds. Principals and Agents: The Structure of Business, Harvard Business School Press, Boston, 37-51.

Avant, D. A. 2005. The Market for Force: The Consequences of Privatizing Security. Cambridge University Press, Cambridge, UK.

Barney, J. B. 1991. Firm resources and sustained competitive advantage. J. Management 17(1) 99-120.

Barney, J. B. 2005. Should strategic management research engage public policy issues? Acad. Management J. 48(6) 945-948.

Barzel, Y. 1989. An Economic Analysis of Property Rights. Cambridge University Press, Cambridge, UK.

Baum, J. A. C., A. M. McGahan. 2009. Outsourcing war: The rise of private military companies after the Cold War. Working paper, University of Toronto, Toronto.

Baumol, W. J. 1991. Perfect Markets and Easy Virtue. Blackwell, Oxford, UK.

Bell, G. G., A. Zaheer. 2007. Geography, networks and knowledge flow. Organ. Sci. 18(6) 955-972.

Bhagwati, J. N. 2005. Reshaping the WTO. Far Eastern Econom. Rev. 168(2) 25-30.

Black, M. 1992. A Cause for our Times: Oxfam and the First 50 Years. Oxfam Publishing, Oxford, UK.

Bonardi, J.-P., A. J. Hillman, G. D. Keim. 2005. The attractiveness of political markets: Implications for firm strategy. Acad. Management Rev. 30(2) 397-413.

Brandenburger, A., G. Stuart. 1996. Value-based business strategy. J. Econom. Management Strategy 5(1) 5-24.

Buchanan, J. M. 1986. Liberty, Market and the State: Political Economy in the 1980s. New York University Press, New York.

Buchanan, J. M., G. Tullock. 1962. The Calculus of Consent. University of Michigan Press, Ann Arbor.

Burch, P. 2009. Hidden Markets: The New Education Privatization. Routledge, New York. 
Capron, L., O. Chatain. 2008. Competitors' resource-oriented strategies: Acting on competitors' resources through interventions in factor markets and political markets. Acad. Management Rev. 33(1) 97-121.

Carlsson, B. 2008. Entrepreneurship and innovation-Organizations, institutions, systems and regions. Paper presented at the 25th Druid Celebration Conference, June 17-20, Copenhagen, Denmark.

Coase, R. H. 1937. The nature of the firm. Economica 4(16) 386-405.

Coase, R. H. 1960. The problem of social cost. J. Law Econom. 3(October) 1-44.

Coase, R. H. 1988. The Firm, the Market and the Law. University of Chicago Press, Chicago.

Coleman, M., M. Lacour-Little, K. D. Vandell. 2008. Sub-prime lending and the housing bubble. J. Housing Econom. 17(4) 272-290.

Convery, F., D. Ellerman, C. D. Perthuis. 2008. The European carbon market in action: Lessons from the first trading period. Working Paper 0802, Massachusetts Institute of Technology, Center for Energy and Environmental Policy Research, Cambridge.

Cowan, A. M., C. D. Cowan. 2004. Default correlation: An empirical investigation of a sub-prime lender. J. Banking Finance 28(4) $753-771$.

Cyert, R. M., J. G. March. 1963. A Behavioral Theory of the Firm. Prentice Hall, Englewood Cliffs, NJ.

Dahlman, C. J. 1979. The problem of externality. J. Law Econom. 22(1) 141-162.

De la Mothe J., Paquet, G. 1996. Evolutionary Economics and the New International Political Economy. Pinter, London.

Demyanyk, Y., O. V. Hemet. 2008. Understanding the subprime mortgage crisis. Federal Reserve Bank of St. Louis, St. Louis, MO, $1-39$.

Dharwadkar, R., M. Goranova, P. Brandes, R. Khan. 2008. Institutional ownership and monitoring effectiveness: It's not just how much but what else you own. Organ. Sci. 19(3) 419-440.

Doering, O. C. 2007. The political economy of public goods: Why economists should care. Amer. J. Agricultural Econom. 89(5) $1125-1133$.

Donaldson, T., L. E. Preston. 1995. The stakeholder theory of the corporation: Concepts, evidence and implications. Acad. Management Rev. 20(1) 85-91.

Dunbar, R., W. Starbuck. 2006. Learning to design organizations and learning from designing them. Organ. Sci. 17(2) 171-178.

Dunning, J. H. 1993. Multinational Enterprise and the Global Economy. Addison-Wesley, Reading, MA.

Easterly, W. 2006. The White Man's Burden: Why the West's Efforts to Aid the Rest Have Done So Much Ill and So Little Good. Penguin Press, New York.

Fagerberg, J., D. Mowery, R. R. Nelson, eds. 2005. The Oxford Handbook of Innovation. Oxford University Press, Oxford, UK.

Foss, K., N. J. Foss. 2005. Resources and transaction costs: How property rights economics furthers the resource-based view. Strategic Management J. 26(6) 541-555.

Foster, R., S. Kaplan. 2001. Creative Destruction: Why Companies that Are Built to Last Underperform the Market and How to Successfully Transform Them. Random House, New York.

Freeman, C. 1988. Japan: A new national system of innovation? G. Dosi, C. Freeman, R. Nelson, G. Silverberg, L. Soete, eds. Technical Change and Economic Theory. Pinter, London, 330-348.
Garrett, L. 2007. The challenge of global health. Foreign Affairs 86(1) $1-17$.

Gilbo, P. F. 1987. The American Red Cross. Chelsea House, New York.

Glachant, J.-M. and S. Saussier. 2006. Introduction to the special issue on public-private partnerships. Rev. Indust. Organ. 29(1) 1-2.

Glasberg, D., D. Skidmore. 1997. Corporate Welfare Policy and the Welfare State: Bank Deregulation and the Savings and Loan Bailout. Aldine Transaction Publishers, Piscataway, NJ.

Gottschalg, O., M. Zollo. 2007. Interest alignment and competitive advantage. Acad. Management Rev. 32(2) 418-437.

Grabowski, R. 1994. The successful developmental state: Where does it come from? World Development 22(3) 413-422.

Gupta, A. K., P. E. Tesluck, M. S. Taylor. 2007. Innovation at and across multiple levels of analysis. Organ. Sci. 18(6) 885-897.

Hahn, R. W., P. C. Tetlock. 2006. A new approach for regulating information markets. J. Regulatory Econom. 29(3) 265-281.

Hambrick, D. C., A. V Werder, E. J. Zajac. 2008. New directions in corporate governance research. Organ. Sci. 19(3) 381-385.

Hart, O. 1995a. Firms, Markets and Financial Structure. Clarendon Press, Oxford, UK.

Hart, O. 2003. Incomplete contract and public ownership: Remarks, and an application to public-private partnership. Econom. J. 113(3) 69-76.

Hart, S. 1995b. A natural-resource-based view of the firm. Acad. Management Rev. 20(4) 986-1014.

Hausmann, R., D. Rodrik, C. F. Sabel. 2008. Reconfiguring industrial policy: A framework with an application to South Africa. Paper presented at the 25th DRUID Celebration Conference, June, Copenhagen, Denmark.

Helfat, C., S. Finkelstein, W. Mitchell, M. Peteraf, H. Singh, D. Teece, S. G. Winter. 2007. Dynamic Capabilities: Understanding Strategic Change in Organizations. Blackwell Publishing, Malden, MA.

Henisz, W. J., B. A. Zelner. 2003. The strategic organization of political risks and opportunities. Strategic Organ. 1(4) 451-460.

Hillman, A. J., M. A. Hitt. 1999. Corporate political strategy formulation: A model of approach, participation, and strategy decision. Acad. Management Rev. 24(4) 825-842.

Hillman, A. J. G. D. Keim, D. Schuler. 2004. Corporate political activity: A review and research agenda. J. Management 30(6) 837-857.

Hillman, A. J., A. Zardkoohi, L. Bierman. 1999. Corporate political strategies and firm performance: Indications of firm-specific benefits for personal services in the U.S. government. Strategic Management J. 20(1) 67-81.

Hirschman, A. O. 1982. Shifting Involvements: Private Interest and Public Action. Princeton University Press, Princeton, NJ.

Hitt, M. A. 2005. Management theory and research potential contribution to public policy and public organizations. Acad. Management J. 48(6) 963-966.

Hope, C. 2008. The impacts of climate change: What do we know, how do we know it, and what should we do? Presentation at the Joint Judge Business School/CIBAM Symposium on Energy, June, Cambridge, UK.

Howard, R. W., J. Preisman. 2007. The bankrupt "revolution": Running schools like businesses fails the test. Ed. Urban Soc. 39(2) 244-263. 
Huet, F., S. Saussier. 2003. Contractual arrangements and the provision of public interest services: A transaction cost analysis. Eur. Bus. Organ. Law Rev. 4 403-427.

International Journal of Industrial Organization. 2008. [Special issue on public-private partnerships] 26(2).

Jacobides, M. G. 2008. Financial meltdown, global recession, and academic failings: Why we should have known better and why we need to understand industry architectures. Working paper, London Business School, London.

Jensen, M. 1983. Organization theory and methodology. Accounting Rev. 50(2) 319-339.

Jorde, T. M., D. J. Teece 1990. Innovation and cooperation: Implications for competition and antitrust. J. Econom. Perspectives 4(3) 75-96.

Just, R. E., S. Netanyahu, L. J. Olson. 2004. Depletion of natural resources, technological uncertainty, and the adoption of technological substitutes. Resource Energy Econom. 27(2) 91-108.

Kaldor, N. 1972. The irrelevance of equilibrium economics. Econom. J. 82(328) 1237-1255.

Kaplan, S., F. Murray. 2009. Entrepreneurship and the construction of value in biotechnology. Res. Sociol. Organ. Forthcoming.

Kapur, D. 2002. The common pool dilemma of global public goods. World Development 30(3) 337-354.

Kaul, I., I. Grunberg, M. A. Stern 1999. Global Public Goods: International Cooperation in the 21st Century. Oxford University Press, Oxford, UK.

Kim, J., J. T. Mahoney. 2002. Resource-based and property rights perspectives on value creation: The case of oil field unitization. Managerial Decision Econom. 23(4) 225-245.

Kim, J., J. T. Mahoney. 2005. Property rights theory, transaction costs theory, and agency theory: An organizational economics approach to strategic management. Managerial Decision Econom. 26(4) 223-242.

Kindleberger, C. P. 1986. International public goods without international government. Amer. Econom. Rev. 76(1) 1-13.

Klein, P., A. McGahan, J. Mahoney, C. Pitelis. 2009. The economic organization of public entrepreneurship. Working paper, University of Illinois at Urbana-Champaign, Champaign.

Knott, A. M., H. E. Posen. 2005. Is failure good? Strategic Management J. 26(7) 617-641.

Krueger, A. 1974. The political economy of the rent-seeking society. Amer. Econom. Rev. 64(3) 291-303.

Krugman, P., A. Smith, eds. 1994. Empirical Studies of Strategic Trade Policy. National Bureau of Economic Research, University of Chicago Press, Chicago.

Lazonick, W., M. O’Sullivan 1996. Organization, finance and international competition. Indust. Corporate Change 5(1) 1-49.

Lee, A. I., J. Alm. 2004. The Clean Air Act amendments and firm investment in pollution abatement equipment. Land Econom. 80(3) 433-447.

Lenox, M. J. 2006. The role of private decentralized institutions in sustaining industry self-regulation. Organ. Sci. 17(6) 677-690.

Lev, B. 2003. Corporate earnings: Facts and fiction. J. Econom. Perspectives 17(2) 403-427.

Libecap, G. D. 1989. Contracting for Property Rights. Cambridge University Press, Cambridge, UK.

Lively, C. 1978. Pluralism and consensus. P. Birnbaum, G. Parry, J. Lively, eds. Democracy, Consensus and Social Contract. Sage Publications, London, 188-202.
Lowenstein, R. 2000. When Genius Failed: The Rise and Fall of LongTerm Capital Management. Random House, New York.

Lucas, R. E. 1988. On the mechanics of economic development. J. Monetary Econom. 22(1) 3-42.

Luger, S. 2000. Corporate Power, American Democracy, and the Automobile Industry. Cambridge University Press, New York.

Lundvall, B., ed. 1992. National Systems of Innovation: Towards a Theory of Innovation and Interactive Learning. Pinter, London.

Lundvall, B. 2007. National innovation systems-Analytical concept and development tool. Indust. Innovation 14(1) 95-119.

Mahoney, J. T. 2005. Economic Foundations of Strategy. Sage, Thousand Oaks, CA.

Mahoney, J. T., A. M. McGahan. 2007. The field of strategic management within the evolving science of strategic organization. Strategic Organ. 5(1) 79-99.

Maritan, C. A., R. E. Florence. 2008. Political activity as strategic factor market competition. Paper presented at Strategic Management Society Conference, October, Cologne, Germany.

Martimort, D., J. Pouyet. 2008. To build or not to build: Normative and positive theories of public-private partnerships. Internat. J. Indust. Organ. 26(2) 393-411.

Mayer, K. J., N. S. Argyres. 2004. Learning to contract: Evidence from the personal computer industry. Organ. Sci. 15(4) 394-410.

McDonald, D. C., ed. 1990. Private Prisons and the Public Interest. Rutgers University Press, New Brunswick, NJ.

McGahan, A. M. 2007a. The limitations of the limited-liability, publicly traded corporation. Working paper, University of Toronto, Toronto.

McGahan, A. M. 2007b. Academic research that matters to managers: On zebras, dogs, lemmings, hammers, and turnips. Acad. Management J. 50 748-753.

McGahan, A. 2009. The end of oil. Rotman Magazine (Winter): 23-27.

McGahan, A. M., M. E. Porter. 2003. The emergence and sustainability of abnormal profits. Strategic Organ. 1(1) 79-108.

McLean, B., P. Elkind. 2003. Smartest Guys in the Room: The Amazing Rise and Scandalous Fall of Enron. Penguin Books, New York.

Mishan, E. 1982. Introduction to Political Economy. Hutchinson, London.

Moran, P., S. Ghoshal. 1999. Markets, firms, and the process of economic development. Acad. Management Rev. 24(3) 390-412.

Morris, J. C. 2007. Government and market pathologies of privatization: The case of prison privatization. Politics Policy 35(2) 318-341.

Mueller, D. C. 2003. Public Choice. Cambridge University Press, Cambridge, UK.

Mueller, D. C. 2006. Corporate governance and economic performance. Internat. Rev. Appl. Econom. 20(5) 623-643.

Muraskin, H. 2006. Revolution in International Health? Origins of the Bill and Melinda Gates Children's Vaccine Program and the Birth of a Global Alliance. University of Rochester Press, Rochester, NY.

Murray, F., S. O'Mahony. 2007. Exploring the foundations of cumulative innovation: Implications for organization science. Organ. Sci. 18(6) 1008-1021.

Nelson, R. R., ed. 1993. National Innovation Systems: A Comparative Analysis. Oxford University Press, New York. 
Nelson, R. R. 2007. The changing institutional requirements for technological and economic catch up. Internat. J. Tech. Learn., Innovation Development 1(1) 4-12.

Nelson, R. R., S. G. Winter. 1982. An Evolutionary Theory of Economic Change. Belknap/Harvard University Press, Cambridge, MA.

Nelson, R. R., S. G. Winter. 2002. Evolutionary theorizing in economics. J. Econom. Perspectives 16(2) 23-46.

Nickerson, J. A., T. Zenger. 2006. A knowledge-based theory of the firm-A problem-solving approach. Organ. Sci. 15(6) 617-632.

North, D. C. 1981. Structure and Change in Economic History. Norton, New York

North, D. C. 1990. Institutions, Institutional Change, and Economic Performance. Cambridge University Press, Cambridge, UK.

North, D. C. 1991. Institutions. J. Econom. Perspectives 5(1) 97-112.

North, D. C. 2005. Understanding the Process of Economic Change. Princeton University Press, Princeton, NJ.

Oliver, C., I. Holzinger. 2008. The effectiveness of strategic political management: A dynamic capabilities framework. Acad. Management Rev. 33(2) 496-520.

Olson, M. 1971. The Logic of Collective Action. Harvard University Press, Cambridge, MA.

Ostrom, E. 1990. Governing the Commons: The Evolution of Institutional Forms of Collective Action. Cambridge University Press, Cambridge, UK.

Ouchi, W. G. 2006. Power to the Principals: Decentralization in three large school districts. Organ. Sci. 17(2) 298-307.

Ouchi, W. G., R. Riordan, L. Lingle, L. Porter. 2005. Making public schools work: Management reform as the key. Acad. Management Rev. 48(6) 929-940.

Penrose, E. T. 1959. The Theory of the Growth of the Firm. Oxford University Press, Oxford, UK.

Peteraf, M. 1993. The cornerstone of competitive advantage. Strategic Management J. 14(3) 179-191.

Pitelis, C. N. 2004. (Corporate) governance, (shareholder) value and (sustainable) economic performance. Corporate Governance: An Internat. Rev. 12(2) 210-223.

Pitelis, C. 2007a. A behavioral resource-based view of the firm-The synergy of Cyert and March (1963) and Penrose (1959). Organ. Sci. 18(3) 478-490.

Pitelis, C. 2007b. European industrial and competition policy: Perspectives, trends and a new approach. Policy Stud. 28(4) $365-381$.

Pitelis, C. N. 2009. The sustainable competitive advantage and catching-up of nations: FDI, clusters, and the liability (asset) of smallness? Management Internat. Rev. 49(1) 95-120.

Porter, M. E. 1990. The Competitive Advantage of Nations. Free Press, Boston.

Porter, M. E. 1998. Clusters and the new economics of competition. Harvard Bus. Rev. 76(6) 77-90.

Posner, R. A. 1974. Theories of economic regulation. Bell J. Econom. 5(2) 335-358.

Post, J. E., L. E. Preston, S. Sachs. 2002. Redefining the Corporation: Stakeholder Management and Organizational Wealth. Stanford Business Books, Stanford, CA.

Putnam, R. D. 1993. Making Democracy Work-Civic Traditions in Modern Italy. Princeton University Press, Princeton, NJ.
Ramamurti, R. 2004. Developing countries and MNEs: Extending and enriching the research agenda. J. Internat. Bus. Stud. 35(4) 277-283.

Rangan, S., R. Samii, L. Van Wassenhove. 2006. Constructive partnerships: When alliances between private firms and public actors can enable creative strategies. Acad. Management Rev. 31(3) 738-751.

Richardson, G. 1972. The organisation of industry. Econom. J. 82(326) 883-896

Robbins, L. 1935. An Essay on the Nature and Significance of Economic Science. Macmillan, London.

Rodrik, D. 2004. Industrial policy for the twenty-first century. CEPR Discussion Paper 4767, Centre for Economic Policy Research, London.

Romer, P. M. 1986. Increasing returns and long-run growth. J. Political Econom. 94(5) 1002-1037.

Rosenberg, N., L. Birdzell 1986. How the West Grew Rich. I. B. Tauris, London.

Rothaermel, F. T, A. M. Hess. 2007. Building dynamic capabilities: Innovation driven by individual-, firm- and network-level effects. Organ. Sci. 18(6) 898-921.

Scherer, F. M., D. Ross 1990. Industrial Market Structure and Economic Performance. Houghton Mifflin, Boston.

Schuler, D. A., K. Rehbein, R. D. Cramer. 2002. Pursuing strategic advantage through political means: A multivariate approach. Acad. Management J. 45(4) 659-672.

Schumpeter, J. A. 1934. The Theory of Economic Development. Harvard University Press, Cambridge, MA.

Schumpeter, J. A. 1942. Capitalism, Socialism and Democracy. Harper \& Row, New York.

Sen, A. K. 1970. Collective Choice and Social Welfare. Holden Day, San Francisco.

Shapiro, H., L. Taylor. 1990. The state and industrial strategy. World Development 18(6) 861-878.

Shepsle, K., B. Weingast 1981. Structure-induced equilibrium and legislative choice. Public Choice 37(3) 503-519.

Simon, H. A. 1976. Administrative Behavior, 3rd ed. Macmillan, New York.

Simon, H. A. 1995. Organizations and markets. J. Public Administration Res. Theory 5(3) 273-295.

Singer, P. W. 2003. Corporate Warriors: The Rise of the Privatized Military Industry. Cornell University Press, Ithaca, NY.

Smith, A. 1776. An Inquiry into the Nature and Causes of the Wealth of Nations. Random House, New York.

Smith, W. K., Tushman, M. L. 2005. Managing strategic contradictions: A top management model for managing innovation streams. Organ. Sci. 16(5) 522-536.

Song, M., R. J. Calantone, C. A. Di Benedetto. 2002. Competitive forces and strategic choice decisions: An experimental investigation in the United States and Japan. Strategic Management J. 23(10) 969-978.

Spulber, D. F. 1989. Regulation and Markets. MIT Press, Cambridge, MA.

Squires, S. E., C. J. Smith, L. McDougal, W. R. Yeack. 2003. Inside Arthur Andersen: Shifting Values, Unexpected Consequences. Prentice Hall, Upper Saddle River, NJ.

Stern, N. 2008. The economics of climate change. Amer. Econom. Rev. 98(2) 1-37.

Stern, G. H., R. J. Feldman. 2004. Too Big to Fail: The Hazards of Bank Bailouts. Brookings Institution Press, Washington, DC. 
Stigler, G. J. 1971. The theory of economic regulation. Bell J. Econom. 2(1) 3-21.

Stiglitz, J. E. 1989. Markets, market failures and development. Amer. Econom. Rev. 79(2) 197-203.

Stiglitz, J. E. 1998. The private uses of public interests: Incentives and institutions. J. Econom. Perspectives 12(2) 3-22.

Stiglitz, J. E. 1999. Knowledge as a global public good. I. Kaul, I. Grunberg, M. A. Stern, eds. Global Public Goods: International Cooperation in the 21st Century. Oxford University Press, Oxford, UK, 308-325.

Stiglitz, J. 2007. Financial hypocrisy. Economists' Voice 4(6) 1-3.

Stiglitz, J. 2008. We aren't done yet: Comments on the financial crisis and bailout. Economists' Voice 10 1-4.

Sutton, J. 1998. Technology and Market Structure: Theory and History. MIT Press, Cambridge, MA.

Teece, D. J. 1982. Towards an economic theory of the multiproduct firm. J. Econom. Behav. Organ. 3(1) 39-63.

Teece, D. J. 2007. Explicating dynamic capabilities: the nature and microfoundations of (sustainable) enterprise performance. Strategic Management J. 28(13) 1319-1350.

Teece, D. J., Pisano, G., A. Shuen 1997. Dynamic capabilities and strategic management. Strategic Management J. 18(7) 509-533.

Thursby, J. G., M. C. Thursby. 2002. Who is selling the ivory tower? Sources of growth in university licensing. Management Sci. 48(1) 90-114.

Tirole, J. 1988. The Theory of Industrial Organization. MIT Press, Cambridge, MA.

Tobin, J. 1980. Asset Accumulation and Economic Activity: Reflections on Contemporary Macroeconomic Theory. University of Chicago Press, Chicago.
Tukey, J. W. 1962. The future of data analysis. Ann. Math. Statist. 33(1) $1-67$.

Tullock, G. 1989. The Economics of Special Privilege and Rent Seeking. Kluwer Academic Publishers, Boston.

Vincent, A. 1987. Theories of the State. Blackwell, Oxford, UK.

Walsh, J. P., K. Weber, J. Margolis. 2003. Social issues and management: Our lost cause found. J. Management 29(6) 859-881.

Watson, M. 2006. Children and war. Lecture given by Mattito Watson, Deputy Field Office Director for Save the Children/U.S., November 8, University of Illinois at Urbana-Champaign, Champaign.

Wernerfelt, B. 1984. The resource-based view of the firm. Strategic Management J. 5(2) 171-180.

White, L. 1991. The S\&L Debacle: Public Policy Lessons for Bank and Thrift Regulation. Oxford University Press, New York.

Williamson, O. E. 1985. The Economic Institutions of Capitalism. Free Press, New York.

Williamson, O. E. 1991. Comparative economic organization: The analysis of discrete structural alternatives. Admin. Sci. Quart. 36(2) 269-296.

Williamson, O. E. 1996. The Mechanisms of Governance. Oxford University Press, New York.

Yang, A., P. E. Farmer, A. M. McGahan. 2008. Sustainability in global health. Working paper, Harvard Medical School Division of Social Medicine, Boston, MA.

Yoshikawa, T., L. S. Tsui-Auch, J. McGuire. 2007. Corporate Governance reform as institutional innovation: The case of Japan. Organ. Sci. 18(6) 973-988.

Zingales, L. 2008. Why Paulson is wrong. Economists' Voice (September) 1-3. 